\title{
Quorum sensing of microalgae associated marine Ponticoccus sp. PD-2 and its algicidal function regulation
}

\author{
Wendan Chi ${ }^{1}$, Li Zheng ${ }^{1,2^{*}}$, Changfei He ${ }^{1}$, Bin Han ${ }^{1}$, Minggang Zheng ${ }^{1}$, Wei Gao ${ }^{1}$, Chengjun Sun ${ }^{1,2}$, Gefei Zhou ${ }^{3}$ \\ and Xiangxing $\mathrm{GaO}^{4}$
}

\begin{abstract}
Quorum sensing (QS) systems play important roles in regulating many physiological functions of microorganisms, such as biofilm formation, bioluminescence, and antibiotic production. One marine algicidal bacterium, Ponticoccus sp. PD-2, was isolated from the microalga Prorocentrum donghaiense, and its $\mathrm{N}$-acyl-homoserine lactone (AHL)mediated QS system was verified. In this study, we analyzed the AHLs profile of strain PD-2. Two AHLs, 3-Oxo-C8-HSL and 3-oxo-C10-HSL, were detected using a biosensor overlay assay and GC-MS methods. Two complete AHL-QS systems (designated $z|a| / R$ and $z|b| / R$ ) were identified in the genome of strain PD-2. When expressed in Escherichia coli, both zlal and zlbl genes could each produce 3-oxo-C8-HSL and 3-oxo-C10-HSL. Algicidal activity was investigated by evaluating the inhibitory rate (IR) of microalgae growth by measuring the fluorescence of viable cells. We found that the metabolites of strain PD-2 had algicidal activity against its host P. donghaiense (IR 84.81\%) and two other red tide microalgae, Phaeocystis globosa (IR 78.91\%) and Alexandrium tamarense (IR 67.14\%). $\beta$-cyclodextrin which binds to AHLs and inhibits the QS system reduced the algicidal activity more than $50 \%$. This indicates that inhibiting the QS system may affect the algicidal metabolites production of strain PD-2. Our study indicated that a QS-regulated algicidal system may play a potential role in the process of red tides disintegration. QS might be a potential way to control red tides.
\end{abstract}

Keywords: AHLs, Algicidal activity, $\beta$-Cyclodextrin, Microalgae-associated bacteria, Quorum sensing

\section{Introduction}

Quorum sensing (QS) is a cell density-dependent system for information transfer among bacteria. It enables the bacterial cells to sense changes in cell density through the concentration of signal molecules called autoinducers (AI) released by bacteria themselves (Guo et al. 2011). When the bacteria grow to a high cell density, the concentration of AI could reach a threshold and bind specifically to a receptor protein. Then, the complex will activate the transcription of target genes and regulate specific functions including biofilm formation,

\footnotetext{
*Correspondence: zhengli@fio.org.cn

${ }^{1}$ Key Laboratory for Marine Bioactive Substances and Modern Analytical Technology of the First Institute of Oceanography, State Oceanic Administration, No. 6 Xianxialing Road, Qingdao 266061, Shandong, People's Republic of China

Full list of author information is available at the end of the article
}

bioluminescence, the secretion of virulence factors, and sporulation (Davies et al. 1998; Greenberg et al. 1979; Nealson et al. 1970). In addition to directly affecting gene regulation, increasing evidences show that cross-kingdom QS signaling between associated bacteria and their hosts also confers other ecological functions indirectly, such as growth-retarding effect of the rotifer (Gambello and Iglewski 1991), the settlement of seaweed zoospores (Joint et al. 2007), and carospore liberation of red macroalgae (Singh et al. 2015). Therefore, QS systems and their regulation functions in bacteria have become hot topics in the fields of marine environment, aquaculture, medicine, and bioengineering.

To date, the most studied intercellular AI molecules are $N$-acyl-homoserine lactones (AHLs), which can be detected by biosensors, gas chromatography-mass spectrometer (GC-MS), and high-performance liquid 
chromatography-mass spectrometer (HPLC-MS) (Li et al. 2015). These AHLs are generated by an autoinducer synthase, the product of a luxI type gene, and the receptor is a cognate luxR type protein. Though there is an increasing number of AHL synthetase genes with some conserved regions in the genomic databases,the overall similarity between luxI homologs from different genera is rather low (Fuqua et al. 1996). Therefore, it is necessary to determine the profiles of AHLs produced by different luxI homologs to better understand the QS system.

Red tides are natural phenomena that are caused by the explosive proliferation of microalgae (Guzmán et al. 2016). Most red tides result in serious environmental problems that are harmful or toxic to humans, fish, shellfish, marine mammals, and birds ( $\mathrm{Hu}$ et al. 2016). The algicidal bacteria that are associated with red tide algae play an important role in controlling their host's biomass. In the initial and developmental stages of red tides, algicidal bacteria show no algicidal activity. In the alage blooming stage, the growth of algicidal bacteria was promoted by the nutrients that are organic materials released by the algae. Subsequently, the bacteria begin to produce algicidal compounds that kill their host cells. It is interesting to find that some algicidal bacteria such as Cytophaga strains J18/M01 (Mirsutani et al. 1992) and A5Y (Imai et al. 1993), Flavobacterium strain 5N-3 (Imai et al. 1992), and Flavobacteriaceae strain S03 (Roth et al. 2007) must reach a cell density of at least $10^{6}$ cells $\mathrm{mL}^{-1}$ before they show any algicidal activity. Li et al. (2014) found that Shewanella sp. Lzh-2 must reach a bacterial cell density threshold of at least $10^{8}$ cells $\mathrm{mL}^{-1}$ before any algicidal compound can be detected. There are also reports that some microalgae could inhibit bacterial quorum sensing activity (Castang et al. 2004). Because algicidal activity is density-dependent, we hypothesize that the algicidal activity of the microalgae associated bacteria may be regulated by QS system and the interaction between microalgae and their associated algicidal bacteria could be mutually restrictive. This probably is an important factor for maintaining the dynamic balance of phycosphere.

It has been proven that QS systems in some bacteria can regulate the production of secondary metabolites, such as antibiotics, including algicidal compounds. One marine bacterium, MS-02-063, belonging to the $\gamma$-proteobacteria, produces a red, algicidal pigment (Nakashima et al. 2006). It is interesting to note that pigment production was also inhibited by adding $\beta$-cyclodextrin $(\beta-C D)$, which forms a complex with AHLs in media, as a QS-quenching substance (Morohoshi et al. 2013). Although it was suggested that the algicidal pigment production was controlled by AHLs-mediated QS, this study neither confirmed the presence of a QS system at the genetic level nor did it find any AHLs molecules. In a subsequent research, Guo et al. (2016) found a bacterium Aeromonas sp.GLY-2107 which could produce two algicidal compounds against Microcystis aeruginosa. They proved that the production of the two algicidal compounds was controlled by QS system. However, this bacterium was screened from freshwater and was not associated with microalgae $M$. aeruginosa. To date, there has been no report on the QS regulated algicidal activity investigated through the interaction between microalgae and their associated bacteria.

In this work, The QS systems of Ponticoccus sp. PD-2, which is a marine microalgae-associated bacterium with algicidal activity, were confirmed by detecting AHL molecules and annotating luxI type autoinducer synthase and $l u x R$ type receptor genes. We analyzed the AHL synthetase functions by introducing LuxI homologes into Escherichia coli. The algicidal activity of strain PD-2 was evaluated and compared after adding $\beta-C D$ into the culture medium. The purpose of this study was to understand AHL-based QS systems in Ponticoccus sp. PD-2, and to prove the hypothesis that the microalgae associated bacterium may kill the host through QS system. We expect to find a novel way to control red tides by biological treatment via enhancing QS activities.

\section{Materials and methods}

\section{Strains and growth conditions}

Ponticoccus sp. PD-2 used in this study was obtained from China General Microbiological Culture Collection Center (CGMCC 1.16027). It was isolated from Prorocentrum donghaiense. Strain PD-2 was grown in marine broth $2216 \mathrm{E}$ (Xu et al. 2012) at $27{ }^{\circ} \mathrm{C}$ with shaking at $150 \mathrm{rpm}$, unless otherwise indicated. E. coli BL21 (DE3) was used to propagate recombinant plasmids and to overexpress zlaI and zlbI proteins. For E. coli strains, the bacteria were grown in Luria-Bertani (LB) medium (Britstein et al. 2016) at $37^{\circ} \mathrm{C}$, with shaking at $150 \mathrm{rpm}$. Transformed cells were grown in LB broth supplemented with $100 \mu \mathrm{g} \mathrm{mL}{ }^{-1}$ ampicillin (Sigma-Aldrich, St. Louis, MO, USA). The microalgae strains included red tide species P. donghaiense CCMM1007, Phaeocystis globosa CCMM5010, and Alexandrium tamarense CCMM1002 (CCMM: Culture Collection of Marine Microalgae). All the indicator microalgae strains were courtesy of the Institute of Oceanography, Chinese Academy of Science and deposited in CMBGCAS. $\mathrm{f} / 2$ medium (Guillard and Ryther 1962) was prepared with seawater collected from the Qingdao shore, and it was filtered through a $0.45-\mu \mathrm{m}$ pore membrane. The medium was autoclaved at $121{ }^{\circ} \mathrm{C}$ for $20 \mathrm{~min}$. The algae were cultured in $\mathrm{f} / 2$ medium at $25{ }^{\circ} \mathrm{C}$ under cool-white fluorescent lamps $(100 \mu \mathrm{mol}$ 
photons $\mathrm{m}^{-2} \mathrm{~s}^{-1}$ ) with a 12:12 light/dark cycle, with shaking three times per day.

The biosensor Agrobacterium tumefaciens KYC55 (pJZ372) (pJZ384, pJZ410), which was provided by Professor Hill at the Institute of Marine and Environmental Technology, University of Maryland, USA. The reporter strain KYC55 (Karina et al. 2013) was prepared by growing it in $1 \times$ ATGN minimal medium (Tempé et al. 1977) with $100 \mu \mathrm{g} \mathrm{mL} \mathrm{m}^{-1}$ spectinomycin dihydrochloride pentahydrate, $4.5 \mu \mathrm{g} \mathrm{mL}{ }^{-1}$ tetracycline, and $100 \mu \mathrm{g} \mathrm{mL} \mathrm{m}^{-1}$ gentamicin at $30{ }^{\circ} \mathrm{C}$, with shaking at $180 \mathrm{rpm}$. A subculture was made in the same medium with an initial 1:500 dilution of the cells. The subculture was grown under the same conditions and harvested when an optical density at $630 \mathrm{~nm}\left(\mathrm{OD}_{630}\right)$ reached 0.35 . The cells were harvested by centrifugation at $15,000 \times g$ for $10 \mathrm{~min}$. The cell pellet was suspended in sterile $30 \%$ glycerol to a calculated $\mathrm{OD}_{630}$ of 12. One-milliliter aliquots of the cells were stored at $-80^{\circ} \mathrm{C}$.

\section{Chemicals}

AHL standards (C6-HSL, 3-oxo-C6-HSL, C8-HSL, 3-oxo-C8-HSL and 3-oxo-C10-HSL) were purchased from the Cayman Chemical Company (Ann Arbor, Michigan, USA). Chromatographic-grade methanol and 99.9\% ethyl acetate were purchased from Sigma-Aldrich (Buchs, Switzerland). The standards were dissolved in methanol at a concentration of $1 \mathrm{mM}$ and stored at $-20^{\circ} \mathrm{C}$.

\section{Extraction of metabolites of strain PD-2}

Bacterial cell suspensions were centrifuged at 12,000 rpm for $5 \mathrm{~min}$. One hundred and fifty milliliters of the cell-free supernatant solution was adjusted to $\mathrm{pH} 7$ with $6 \mathrm{M} \mathrm{HCl}$ solution, preserved overnight at $4{ }^{\circ} \mathrm{C}$, and then extracted according to the procedure described previously (Cataldi et al. 2004, 2007). Briefly, $150 \mathrm{~mL}$ of the cell-free supernatant solution was extracted twice with $150 \mathrm{~mL}$ of ethyl acetate each. The combined organic phases were evaporated by rotary evaporators at $37{ }^{\circ} \mathrm{C}$. The residue was redissolved in $200 \mu \mathrm{L}$ of ethyl acetate and stored at $4{ }^{\circ} \mathrm{C}$.

\section{Analysis of the AHL profile Bioautography analysis}

All AHLs produced by strain PD-2 were screened using the A. tumefaciens KYC555-based biosensor system developed by Zhu et al. (2003). The reporter overlay was prepared by cooling $90 \mathrm{~mL}$ of $0.6 \%$ agar to $40{ }^{\circ} \mathrm{C}$ and adding $5 \mathrm{~mL}$ of $20 \times$ AT salts $\left(15 \mathrm{mM}\left(\mathrm{NH}_{4}\right)_{2} \mathrm{SO}_{4}, 0.6 \mathrm{mM}\right.$ $\mathrm{MgSO}_{4} \cdot 7 \mathrm{H}_{2} \mathrm{O}, 0.06 \mathrm{mM} \mathrm{CaCl} 2 \cdot 2 \mathrm{H}_{2} \mathrm{O}$, and $0.0071 \mathrm{mM}$ $\left.\mathrm{MnSO}_{4} \cdot \mathrm{H}_{2} \mathrm{O}\right), 5 \mathrm{~mL}$ of $20 \times$ AT buffer $(79 \mathrm{mM}$ $\left.\mathrm{KH}_{2} \mathrm{PO}_{4}, \mathrm{pH} 7.0\right), 1 \mathrm{~mL}$ of $50 \%(\mathrm{w} / \mathrm{w})$ glucose, $200 \mu \mathrm{L}$ of $20 \mathrm{mg} \mathrm{mL}^{-1} \mathrm{X}$-gal, and $1 \mathrm{~mL}$ of the prepared the KYC55 cells. Extracts were spotted onto $\mathrm{C} 18$ reverse-phase thin-layer chromatography (TLC) plates (Mallinckrodt Baker, Philipsburg, NJ, USA) and developed with $60 \%$ methanol as the mobile phase. The TLC plates were dried, sterilized with ultraviolet light, and placed in an autoclaved Petri dish. The AHLs reporter overlay was poured on top of the plate. The plate was incubated at $30{ }^{\circ} \mathrm{C}$ overnight to allow the developing of blue colonies that indicate the existence of AHLs.

\section{GC-MS analysis}

The GC-MS analysis was performed according to Cataldi et al. (2007). The analysis of AHLs in the extracts from bacterial cultures was performed by a GC system that was interfaced to a single-quadrupole mass spectrometer (7980A/5975C, Agilent Technologies, Santa Clara, CA, USA). Samples were injected with the split mode (5:1) into an HP-5 MS capillary column, $30 \mathrm{~m} \times 250 \mu \mathrm{m}$ internal diameter and $0.25-\mu \mathrm{m}$-thick film coated with $5 \%$ PhMe siloxane. High-purity helium was used as carrier gas at a flow rate of $1 \mathrm{~mL} \mathrm{~min}^{-1}$. The GC injector temperature was set at $200{ }^{\circ} \mathrm{C}$. The oven temperature program was optimized to hold at $150{ }^{\circ} \mathrm{C}$ for $3 \mathrm{~min}$ and then increase by $28{ }^{\circ} \mathrm{C} \mathrm{min}{ }^{-1}$ up to $280{ }^{\circ} \mathrm{C}$. The transfer line temperature was adjusted to $280{ }^{\circ} \mathrm{C}$. Mass spectrometry conditions were as follows: the electron ionization source was set to $70 \mathrm{eV}$; the emission current was $500 \mu \mathrm{A}$; the MS quad was set to $150^{\circ} \mathrm{C}$; and the MS source was set to $230^{\circ} \mathrm{C}$. The mass spectrometer was run both in full-scan mode $(m / z \quad 15-800)$ and the chromatography analysis performed in SIM mode $(\mathrm{m} / z=143)$.

\section{Analysis of AHL synthases in strain PD-2}

The genome sequence of strain PD-2 was sequenced and analyzed by Majorbio Co., Ltd. (Shanghai, China). The whole genome of strain PD-2 was submitted to GenBank (AWRV02000000) (Zheng et al. 2015). From the annotated sequences of Ponticoccus sp. PD-2, two clusters of $l u x I$ and $l u x R$ homologues were identified. After analyzing the candidate genes related to AHL production we found two AHL-sythase genes. The first AHL-sythase gene named zlaI is located in contig 600 with a length of $870 \mathrm{bp}$. The second AHL-synthase gene named $z l b I$ is located in contig 616 with a length of $639 \mathrm{bp}$. The two AHL-related genes (luxR family transcriptional regulator), zlaR and $z l b R$, were located in the upstream position of $z l a I$ and $z l b I$, respectively. Each cluster of the luxI and luxR genes is contiguous. The two QS (luxI/R homologs) genes were named $z l a I / R$ and $z l b I / R$ respectively. Comparative analysis of the $z l a I / R$ and $z l b I / R$ sequences and the closest related sequences were performed in the National Center for Biotechnology Information database (http://www.ncbi.nlm.nih.gov), and homologous proteins were retrieved using the protein Basic Local Alignment 
Search Tool (BLASTP). Sequences were aligned using DNASTAR.Lasergene.v7.1 software. A phylogenetic tree was constructed with MEGA 7.0 software (Kumar et al. 2016), using the neighbor-joining algorithm with 1000 permutations.

\section{DNA manipulations}

The complete sequences of the $z l a I$ and $z l b I$ genes were amplified by polymerase chain reaction (PCR). Primers with the following sequences were used: zlaI-F ( $5^{\prime}$-CGGG ATCCATGAATGGAGTGGTCAAAAT-3'), zlaI-R ( $5^{\prime}-\mathrm{C}$ CCTCGAGTCAGGCCCGCTTTGCCTTCA-3'), zlbI-F (5'-CGGGATCCATGATCCGCTACATCTACGG-3'), and zlb-R (5'-CCCTCGAGTCAGGCGGCAACCATCTG CT- $\left.3^{\prime}\right)$. The $5^{\prime}$-end primer included a BamHI restriction site, and the $3^{\prime}$-end primer included an XhoI restriction site. PCR was performed by incubation for $2 \mathrm{~min}$ at $95^{\circ} \mathrm{C}$, followed by 30 cycles of $30 \mathrm{~s}$ at $95^{\circ} \mathrm{C}, 30 \mathrm{~s}$ at $60^{\circ} \mathrm{C}$, and $1 \mathrm{~min}$ at $72{ }^{\circ} \mathrm{C}$, with a final elongation step of $10 \mathrm{~min}$ at $72{ }^{\circ} \mathrm{C}$.

\section{Function determination}

The amplified zlaI and $z l b I$ genes were cloned into pGEX-6P-1, and the resulting recombinant plasmids were labeled as pGEX-zlaI and pGEX-zlbI, respectively. These two plasmids were transformed into $E$. coli BL21 (DE3). The sequence of zlaI and $z l b I$ cloned into pGEX-6P-1 plasmid were verified by PCR with primers (F:5'-GGGCTGGCAAGCCACGTTTGGTG-3'; R:5'-CCGGGAGCTGCATGTGTCAGAGG-3'). Then, the transformants were grown on LB plate containing ampicillin $\left(100 \mu \mathrm{g} \mathrm{mL} \mathrm{m}^{-1}\right)$ at $37^{\circ} \mathrm{C}$ for $24 \mathrm{~h}$ with shaking at $150 \mathrm{rpm}$. The AHLs production profiles of these two transformants were analyzed as described in the bioautography analysis section.

\section{Effects of $\beta-C D$ on the growth of strain PD-2}

The effects of $\beta-C D$ on the growth of strain PD-2 were tested before determining the effects of $\beta$-CD on autoinducer activities. Strain PD-2 was inoculated into 2216E medium and incubated at $27{ }^{\circ} \mathrm{C}$, with shaking at $150 \mathrm{rpm}$ for $20 \mathrm{~h}$. Then, the bacterial cultures were mixed with various concentrations of $\beta$-CD solutions (final concentrations of $\beta$-CD were 1,2 , and $5 \mathrm{mg} \mathrm{mL}^{-1}$ respectively) and continued incubation at $27{ }^{\circ} \mathrm{C}$ for another $64 \mathrm{~h}$ with shanking $150 \mathrm{rpm}$. Growth curves of the bacteria were plotted according to the periodically measured $\mathrm{OD}_{630} \cdot \beta-\mathrm{CD}$ at a $1 \mathrm{mg} \mathrm{mL} \mathrm{m}^{-1}$ concentration, which had the smallest effects on growth, was selected for the subsequent algae-inhibition experiments to minimize the effects resulting from the addition of $\beta-C D$.

\section{Assessment of algicidal activity}

The algicidal effect of strain PD-2 was assessed as described by Xu et al. (2012). The target species included $P$. donghaiense, $P$. globosa, and A. tamarense. The final concentrations of $P$. donghaiense, $P$. globosa, and $A$. tamarense were adjusted to $1.4 \times 10^{5}, 1.1 \times 10^{6}$ and $2.3 \times 10^{4}$ cells $\mathrm{mL}^{-1}$ at the exponential phase respectively. Strain PD-2 was grown for 20 and $84 \mathrm{~h}$ at $27{ }^{\circ} \mathrm{C}$, with shaking at $150 \mathrm{rpm}$. Metabolites were extracted as described previously. The extracts of the culture were redissolved in dimethyl sulfoxide to a final concentration of $20 \mathrm{mg} \mathrm{mL}^{-1}$. Subsequently, $5 \mu \mathrm{L}$ of the extracts was added to a $10 \mathrm{~mL}$ glass tube containing $5 \mathrm{~mL}$ of the algae cultures and incubated at $25^{\circ} \mathrm{C}$. Meanwhile, as a control, $5 \mu \mathrm{L}$ of an extract of 2216E medium was added to $5 \mathrm{~mL}$ of the algae cultures after 5 day of cocultivation. The algicidal activities were measured by the fluorescence method under the conditions of EX (excitation spectrum $)=463 \mathrm{~nm} / \mathrm{EM}($ emission spectrum $)=640 \mathrm{~nm}$.

The inhibition rate (IR, \%) was calculated based on the following equation:

$$
\mathrm{IR}=\frac{F_{\text {control }}-F_{\text {treatment }}}{F_{\text {control }}} \times 100 \%
$$

where Ftreatment and Fcontrol represent the fluorescence values in the treatment and control, respectively.

\section{Investigation of the QS-mediated regulation of the algicidal activity of strain PD-2}

To investigate whether QS regulates algicidal activity, strain PD-2 was initially grown for $20 \mathrm{~h}$ at $27^{\circ} \mathrm{C}$. Then $\beta-C D$ was added to the culture and the culture was incubated for $64 \mathrm{~h}$ at $27^{\circ} \mathrm{C}$, with shaking at $150 \mathrm{rpm}$. Then, the metabolites were extracted to analyze changes in AHLs production and algicidal activity. The method of detecting the production of AHLs and algicidal activity based on bioautography analysis and assessment of algicidal activity respectively.

\section{Results \\ Analysis of the AHL profile Bioautography analysis}

TLC overlay assay with the biosensor KYC55 suggested that strain PD-2 produced two AHLs (Fig. 1). The retardation factor (RF) values of lower spot and upper spot were 0.12 and 0.31 respectively. Five standards (C6, OC6, C8, OC8 and OC10) were shown in Fig. 1. According to the RF values of the AHLs, two AHLs matched standards, which were synthetic $\mathrm{N}$-3-oxo-octanoyl-L-homoserine lactone (3-oxo-C8-HSL) and $\mathrm{N}$-(3-oxodecanoyl)-L-homoserine lactone (3-oxo-C10-HSL). GC-MS experiments were performed subsequently to confirm the AHLs of strain PD-2. 

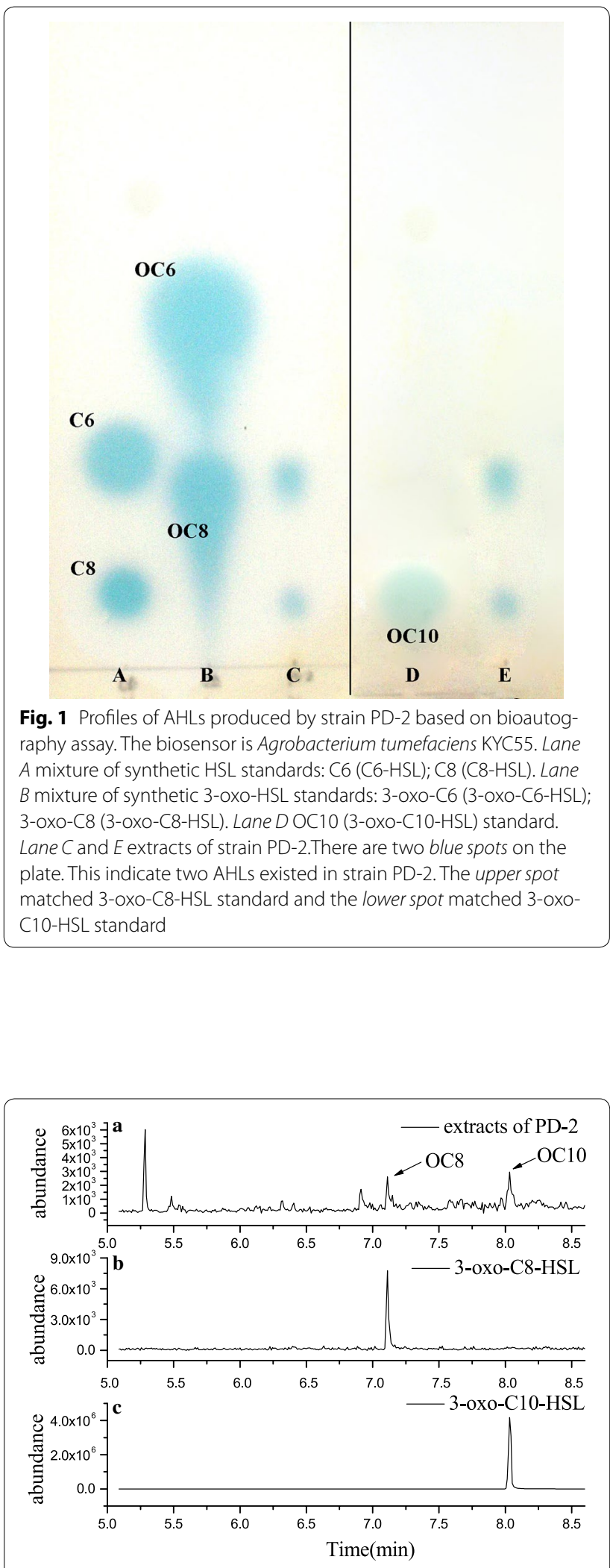

Fig. 2 GC-MS chromatogram in SIM mode at $\mathrm{m} / \mathrm{z} 143$. a Extract of strain PD-2. b 3-oxo-C8-HSL standard, RT = 7.111 min. c 3-oxo-C10HSL standard, RT $=8.033 \mathrm{~min}$

\section{GC-MS analysis}

A chromatography analysis was performed in SIM mode using an ion with $m / z=143$ as a marker fragment. The chromatography of the AHL standards were shown in Fig. $2 \mathrm{~b}$ and c. Through analyzing the MS information, two peaks in PD-2 extracts showed in Fig. 2a of the retention times (RT) were consistent with the standard of 3-oxoC8-HSL and 3-oxo-C10-HSL at 7.111 and $8.033 \mathrm{~min}$.

\section{Comparative genomics and phylogenetic tree}

Web-based similarity searches using the GenBank database were used to determine the homologous degrees of zlaI and zlbI protein sequences to those of other AHL synthases. The most similar homolog of zlaI, identified using a BLASTP search, was an autoinducer synthase from Sulfitobacter pseuddonitzssschiae (GenBank accession no. WP 037926640.1) with a 77\% identity; the most similar homologs of zlbI were autoinducer synthases from Tropicibacter naphthalenivorans and Ponticoccus sp. SJ5A-1(GenBank accession nos. WP 058247237.1 and WP 058863594.1, respectively), with $81 \%$ identity. In fact, the multiple sequence alignments revealed that zlaI and zlbI share low homology, but both shared 10 conserved amino acids with other reported autoinducer proteins of Rhodobacterales bacteria as shown in Additional file 1: Figures S1A, B, respectively. Moreover, the phylogenetic tree constructed based on amino acid alignment (Fig. 3a, b) illustrated that zlaI clustered closely with an autoinducer synthase protein from Salipiger mucosus with a bootstrap value of $88 \%$ and zlbI was the least phylogenetically related to autoinducer synthase proteins from T. naphthalenivorans and Sagittula stellate with a bootstrap value of $52 \%$. The Fig. 3c showed that zlaR clustered closely to an luxR family transcriptional regulator protein from Salipiger mucosus. Figure 3d showed zlbR clustered closely to luxR family transcriptional regulator proteins from Pelagibaca abyssi and Thiobacimonas profunda with a bootstrap value of $53 \%$.

\section{Identification of the zlal and zlbl genes responsible for AHL production}

To identify what kinds of AHLs are produced by the $z l a I$ and $z l b I$ genes, the expression of $z l a I$ and $z l b I$ was examined in an E. coli strain that does not produce AHL. The presence of the $870 \mathrm{bp} z l a I$ and $639 \mathrm{bp} z l b I$ genes in the transformants were confirmed by PCR amplification. In bioautography, the KYC55 biosensor detected AHLs from recombinant $E$. coli culture extracts. In Fig. 4, AHLs signals are observed as blue spots on the plat. This demonstrates $z l a I$ and $z l b I$ encode AHL synthetases in E. coli BL21. The profile of AHLs produced by pGEXzlaI E. coli BL21 and pGEX-zlbI E. coli BL21 indicate that the $z l a I$ and $z l b I$ genes produced the same AHLs of 


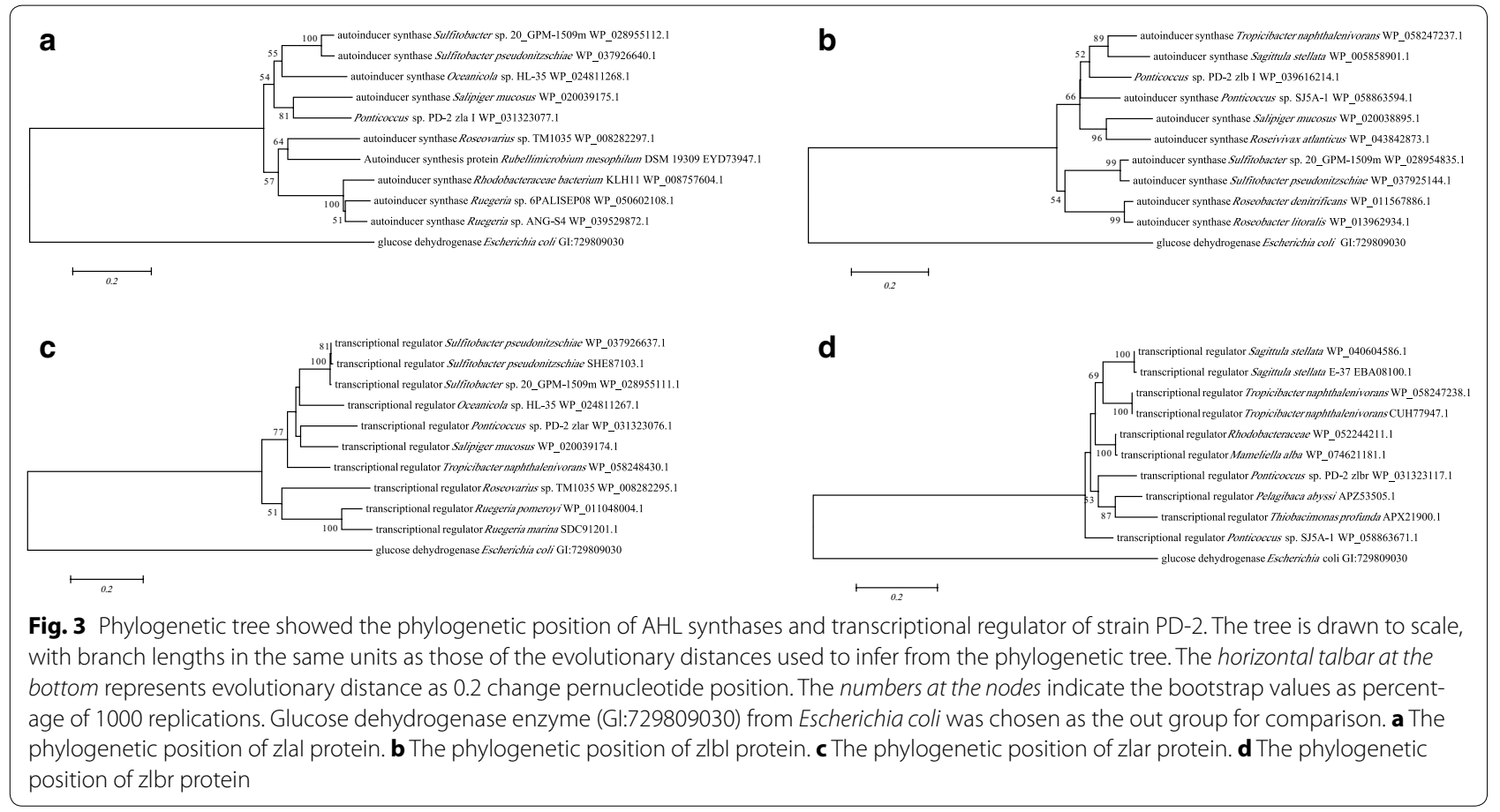

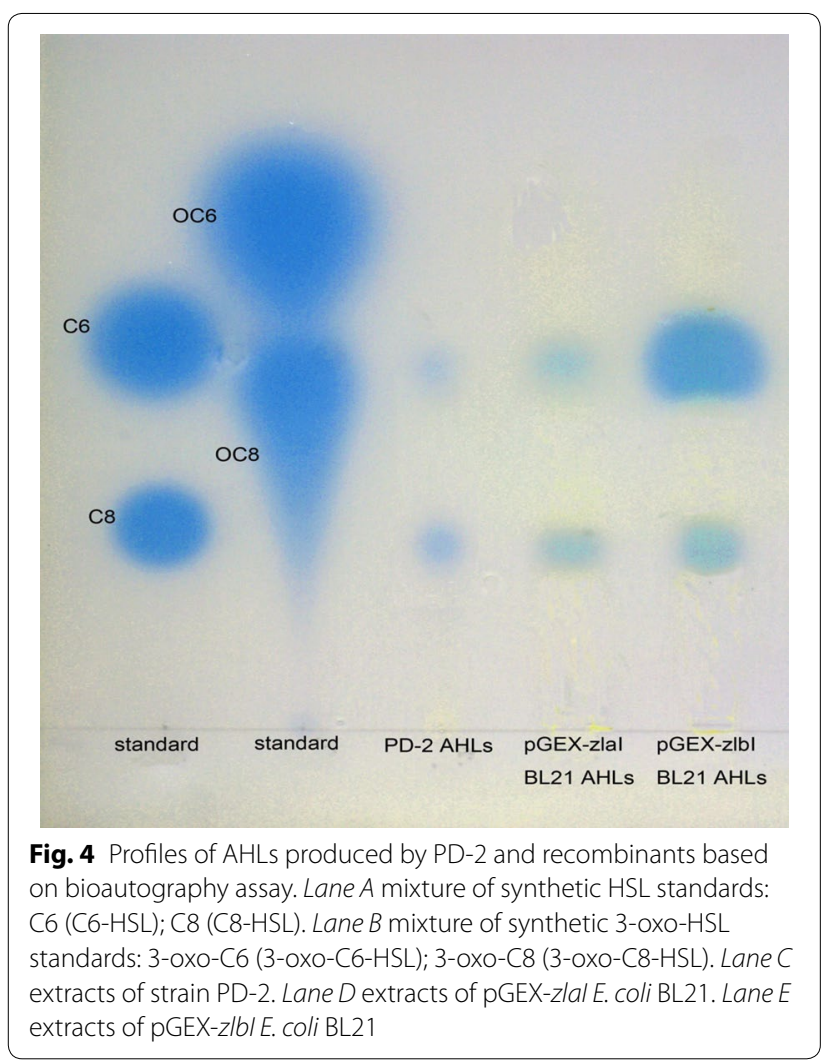

3-oxo-C8-HSL and 3-oxo-C10-HSL (Fig. 4). Although this method cannot determine an absolute quantification, the size of a spot on TLC plate may also reflect the concentrations of AHLs to some degree (Deepa et al. 2012). From the size of each blue spot, the $z l b I$ gene produced obviously greater amounts of 3-oxo-C8-HSL than zlaI, thereby demonstrating that 3 -oxo-C8-HSL is the main product of the $z l b I$ gene.

\section{The effect of $\beta-C D$ on the growth of strain PD-2}

Growth curves with different concentrations of $\beta-C D$ are shown in Additional file 1: Figure S2. No significant differences were found in the initial $40 \mathrm{~h}$ of growth; all the strains entered the logarithmic phase at $10 \mathrm{~h}$ and the plateau phase at $40 \mathrm{~h}$. The $\mathrm{OD}_{630}$ values declined after $40 \mathrm{~h}$ of incubation with $\beta-\mathrm{CD}$. The levels of growth inhibition were proportional to the $\beta-\mathrm{CD}$ concentrations. At $84 \mathrm{~h}$, the $\mathrm{OD}_{630}$ values were $0.67,0.51$, and 0.42 at $\beta-\mathrm{CD}$ concentrations of 1,2 , and $5 \mathrm{mg} \mathrm{mL}^{-1}$, respectively. The curve of the control was much more stable $\left(\mathrm{OD}_{630}\right.$ of 0.7 ) from 40 to $84 \mathrm{~h}$. The results suggested that the addition of $1 \mathrm{mg} \mathrm{mL} \mathrm{m}^{-1} \beta$-CD had the lowest impact on growth with a growth of inhibition of only $4 \%$, which we considered appropriate for the following experiments.

After the addition of $\beta-C D$, the concentrations of the AHLs were detected by bioautography assay (Fig. 5). The spots of samples A (PD-2 cultured for $20 \mathrm{~h}$ at low density) and B (PD-2 cultured for $84 \mathrm{~h}$ at high density), which did not contain $\beta-C D$, were much larger and were deeper blue than $C$ (A adding $\beta-C D$, then cultured for $84 \mathrm{~h}$ ) which was dim blue. This indicates strain PD-2 at low density just produce a small amount of AHLs. When the 


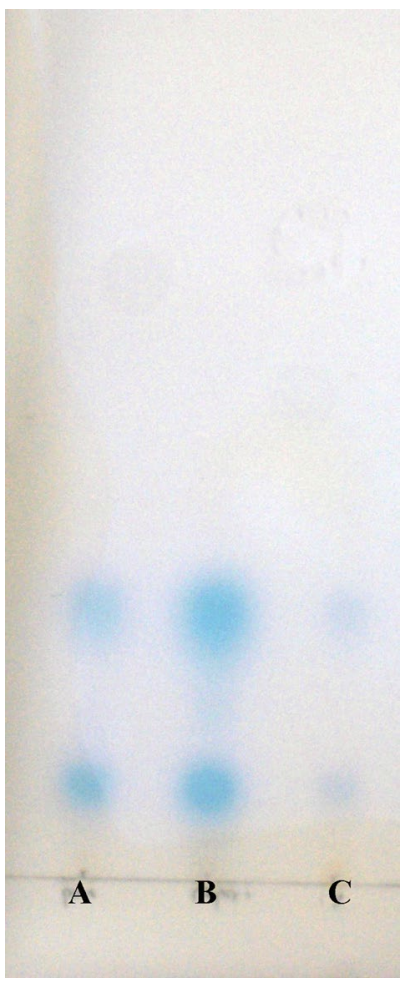

Fig. 5 Profiles of AHLs produced by strain PD-2 under different culture condition. The biosensor is Agrobacterium tumefaciens KYC55. Lane A extracts of strain PD-2 cultured for $20 \mathrm{~h}$. Lane B extracts of strain PD-2 cultured for $84 \mathrm{~h}$. Lane $C$ extracts of strain PD-2 cocultured with $1 \mathrm{mg} \mathrm{mL}^{-1} \beta-C D$ at $20 \mathrm{~h}$ and continuously cultured for $64 \mathrm{~h}$. After overnight incubation, the AHLs production was visually observed as blue spots. There was a positive correlation between the size of the blue spots and the concentration of AHLS

bacterium continuously grows to high cell density, the AHLs accumulate to high concentration. But after adding QS-quenching $\beta-C D$ in the low cell density, the concentration of AHLs do not increase. Because $\beta-C D$ can form complexes with the AHLs that PD-2 produced at high cell density (Morohoshi et al. 2013).

\section{The algicidal effect of Ponticoccus sp. PD-2 on red tide species}

Algicidal activities of strain PD-2 were obtained after 5 days of co-cultivation with target microalgae. The date presented were the mean values of IR from triplicates. (a)
The microalgae which was co-cultured with the extracts of strain PD-2 cultured for $84 \mathrm{~h}$. (b) the microalgae which was co-cultured with the extracts of strain PD-2 cultured for $20 \mathrm{~h}$. (c) the microalgae which was co-cultured with extracts of strain PD-2 co-cultured with $1 \mathrm{mg} \mathrm{mL}^{-1} \beta-C D$ on $20 \mathrm{~h}$ and continuously cultured for $64 \mathrm{~h}$.

Strain PD-2 shows algicidal effects on all red tide species after $84 \mathrm{~h}$ of culturing (Table 1). From the IR value, PD-2 had the strongest algicidal effect (IR 84.81\%) on its host, $P$. donghaiense. Besides its host microalgae, strain PD-2 also had algicidal effects on P. globosa (IR 79.91\%) and a small effect on A. tamarense (IR 67.14\%). After culturing for $20 \mathrm{~h}, \mathrm{PD}-2$ had very little algicidal effects on P. donghaiense and A. tamarense with IR of 20.27 and $18.38 \%$ respectively and no effect on $P$. globosa. The same results were observed when PD-2 was continuously cocultured with $1 \mathrm{mg} \mathrm{mL}^{-1} \beta$-CD for $64 \mathrm{~h}$. Then, the algicidal activities of PD- 2 co-cultured with $\beta$-CD decreased to IR of $19.45 \%$ against $P$. donghaiense and $16.09 \%$ against A. tamarense. Compared to PD-2 without $\beta-\mathrm{CD}$ added, the algicidal activities decrease by more than $50 \%$. In this research, the addition of $\beta-C D$ reduced the concentration of the AHLs. Thus, the results suggest that the algicidal activities of strain PD-2 are regulated by a QS system.

\section{Discussion}

In this study, a Ponticoccus sp. PD-2 strain was isolated from the harmful algal bloom-associated microalga $P$. donghaiense. Its metabolites had growth inhibition effects not only on its host (P. donghaiense), but also on two other red tide microalgae, $P$. globosa and A. tamarense. Ponticoccus was first isolated from the coastal seawaters of Korea and has been identified as a new genus belonging to Rosebacter clade (Hwang and Cho 2008). The Rosebacter clade is one of the major marine groups and has members across diverse marine habitats (Buchan et al. 2005). Bacteria of Rosebacter clade also appear in the symbiotic systems of microalgae and may often regulate the algal community (Kodama et al. 2006; Tan et al. 2015).

To our knowledge, this is the first report demonstrating that Ponticoccus sp. has QS functions. In our previous research, we found strain PD-2 could produce AHLs QS signals. Of the diverse AHLs produced by marine bacteria, the most common types are C4-HSL, C6-HSL,

Table 1 Algicidal effect of strain PD-2 against various red tides microalgae species

\begin{tabular}{llcc}
\hline Inhibition rate (\%) & Prorocentrum donghaiense & Phaeocystis globosa & Alexandrium tamarense \\
\hline A & $84.81 \pm 2.8$ & $78.91 \pm 1.6$ & $67.14 \pm 3.5$ \\
B & $20.27 \pm 3.6$ & $-3.61 \pm 3.1$ & $18.38 \pm 3.3$ \\
C & $19.45 \pm 1.8$ & $-1.94 \pm 2.0$ & $16.09 \pm 2.4$ \\
\hline
\end{tabular}


3-hydroxy-C6-HSL, 3-oxo-C6-HSL, C8-HSL, 3-oxo-C8HSL, 3-oxo-C10-HSL, 3-oxo-c12-HSL and C14-HSL (Berger et al. 2012; Swift et al. 1997; Tang et al. 2013; Zan et al. 2013). The various signal molecules produced by its synthetases (luxI homolog genes) can be investigated by heterologous expression (Gao et al. 2014; How et al. 2015; Morohoshi et al. 2016). To determine which kinds of AHLs are produced by $z l a I$ and $z l b I$, we expressed zlaI and zlbI in E. coli. 3-oxo-C8-HSL and 3-oxo-C10-HSL were identified in a PD-2 extract and in E. coli overexpressing zlaI and zlbI, suggesting that both $z l a I$ and $z l b I$ can each produce two kinds of AHLs. However, it is rare that two homologous luxI genes can generate identical signal molecules in one strain. Thus, we speculate that the two kinds of signal molecule are synthesized from the same metabolic pathway. In this study, the multiple sequence alignment and the phylogenetic tree (Additional file 1: Figure S1; Fig. 3a, b) illustrated that although there was only a low degree of homology, both of PD-2 and other Rhodobacterales bacteria had conserved regions among AHL synthases. Thus, the zlaI gene and $z l b I$ gene should be new AHL synthetase genes. All the strains shared the 10 invariant amino acids that are characteristic of luxI homologs (Parsek et al. 1997). This strongly indicates a low rate of random mutation for this autoinducer. It also shows that these proteobacteria share a similar QS mechanism and a similar mechanism for regulating the synthesis of AHLs, although the corresponding AHLs regulate different target genes. Through comparing zlaR and zlbR protein sequences with those of other LuxR family transcriptional regulator on NCBI and constructing phylogenetic tree (Fig. 3c, d), we found that there was also a low degree of homology among transcriptional regulator from other bacteria. Thus, the zlaR gene and $z l b R$ gene might also be new transcriptional regulator genes.

Many studies have shown that marine organism-associated bacteria play very important roles when interacting with their hosts. In recent years, a high percentage of marine organism-associated bacteria have been shown to produce QS signals, including bacteria associated with microalgae, sponges, corals, and fish (Britstein et al. 2016; Wagner-Döbler et al. 2005). Thus, studying the QS-mediated interactions between marine bacterial with their hosts has profound theoretical and practical significance regarding the ecological functions of marine bacteria. In fact, many investigations have proven that QS regulates such interactions. The luminous bacterium Vibrio fischeri is the specific light organ symbiont of Euprymna scolopes (Boettcher and Ruby 1990) E. scolopes is a small sepiolid squid (average adult length, $40 \mathrm{~mm}$ ) that is indigenous to the Hawaiian archipelago, where it lives in shallow sand flats that are associated with coral reefs (Ruby and McFallngai 1992). The squid buries itself in the sand during the day to escape predators, but it comes out to forage in the water column at night (Summers 1983). Additionally, sponges and their associated microorganisms have developed a variety of chemical defense pathways. The production of chemicals which are regulated via QS systems are employed to defend sponges against potentially pathogenic bacteria and fish predators, deter fouling organisms, and degrade surfactants (Guo et al. 2011; Huang and Li 2006).

Cyclodextrins are a family of compounds comprising sugar molecules that are bound together in a ring. Cyclodextrins are well known cyclic oligosaccharides that form complexes with a wide range of organic compounds. Tsukasa proved that $\alpha, \beta-C D$ could form a complex with an autoinducer in a bacterial culture medium (Ikeda et al. 2002). He found that the addition of $\beta-C D$ decreased the abundance of AHLs signal molecules by $75 \%$, without inhibiting bacterial growth. But our results indicate that $1 \mathrm{mg} \mathrm{mL}^{-1} \beta$-CD had little influence on the growth of strain PD-2, and $\beta$-CD could form a complex with AHLs produced by strain PD-2 in the culture medium (Morohoshi et al. 2013). The algicidal activities of strain PD-2 decreased more than 50\% due to its QS system was inhibited, this is the first evidence that the QS systems of microalgae-associated bacteria can regulate algicidal activity.

Existing evidence proves that production of algicidal substances can be regulated by QS (Guo et al. 2016; Nakashima et al. 2006), although there is no direct evidence to suggest that the algicidal activities of microalgae-associated bacteria is regulated by QS systems. Consequently, investigations of the effects of QS on the regulation of algicidal functions are needed to increase our understanding of the relationship between bacteria and algae, and QS inhibitors can be used to study QS regulation.

\section{Additional file}

Additional file 1. Additional figures.

\begin{abstract}
Abbreviations
QS: quorum sensing; Al: autoinducer; $\mathrm{AHL}$ : N-acyl-homoserine lactone; $\beta-C D$ : $\beta$-cyclodextrin; GC-MS: gas chromatography-mass spectrometer; HPLC-MS: high-performance liquid chromatography-mass spectrometer; LB: LuriaBertani; TLC: thin-layer chromatography; IR: inhibition rate; RF: retardation factor; 3-oxo-C8-HSL: N-3-oxo-octanoyl-L-homoserine lactone; 3-oxo-C10-HSL: $\mathrm{N}$-(3-oxodecanoyl)-L-homoserine lactone; RT: retention times; PCR: polymerase chain reaction; CCMM: culture collection of marine microalgae.
\end{abstract}

\section{Authors' contributions}

WC and $\mathrm{LZ}$ designed the whole experiment; $\mathrm{CH}, \mathrm{BH}$ and $\mathrm{MZ}$ helped to carry the experiment; WG, CS and GZ helped to analyze the raw data; WC wrote the article and XG helpd on the paperwork. All authors read and approved the final manuscript. 


\begin{abstract}
Author details
${ }^{1}$ Key Laboratory for Marine Bioactive Substances and Modern Analytical Technology of the First Institute of Oceanography, State Oceanic Administration, No. 6 Xianxialing Road, Qingdao 266061, Shandong, People's Republic of China. ${ }^{2}$ Laboratory for Marine Ecology and Environmental Science, Qingdao National Laboratory for Marine Science and Technology, Qingdao 266071, People's Republic of China. ${ }^{3}$ School of Life Science of Yantai University, Yantai 264000, People's Republic of China. ${ }^{4}$ National Deep Sea Center, State Oceanic Administration of China, Qingdao 266237, People's Republic of China.
\end{abstract}

\section{Acknowledgements}

We thank Professor Hill from The Institute of Marine and Environmental Technology, University of Maryland, USA, for providing the biosensor Agrobacterium tumefaciens KYC55 ( $\mathrm{pJZ372)}$ ( $\mathrm{pJZ384}, \mathrm{pJZ410)}$. We thank the Institute of Oceanography, Chinese Academy of Science, for providing the indicator microalgae strains.

\section{Competing interests}

The authors declare that they have no competing interests.

\section{Availability of data and materials}

All datasets on which the conclusions of the manuscript rely are presented in the main paper.

\section{Funding}

This work was supported by The National Natural Science Foundation of China-Shandong Joint Funded Project (U1406404), the National Natural Science Foundation of China (41076108), Basic Scientific Fund for National public Reserch Institute of China (2015T05), Marine science and technology project of Huangdao district of Qingdao city (2014-4-20), Natural Science Foundation of Shandong Province (ZR2014DL011), and the 2012 Taishan Scholar Award. All of these funds have been used for purchasing reagents and data analysis.

Received: 23 February 2017 Accepted: 27 February 2017 Published online: 09 March 2017

\section{References}

Berger M, Brock NL, Liesegang H, Dogs M, Preuth I, Simon M, Dickschat JS, Brinkhoff T (2012) Genetic analysis of the upper phenylacetate catabolic pathway in the production of tropodithietic acid by Phaeobacter gallaeciensis. Appl Environ Microbiol 78(10):3539-3551

Boettcher K, Ruby E (1990) Depressed light emission by symbiotic Vibrio fischeri of the sepiolid squid Euprymna scolopes. J Bacteriol 172(7):3701-3706

Britstein M, Devescovi G, Handley KM, Malik A, Haber M, Saurav K, Teta R, Costantino V, Burgsdorf I, Gilbert JA (2016) A new N-Acyl homoserine lactone synthase in an uncultured symbiont of the Red Sea sponge Theonella swinhoei. Appl Environ Microbiol 82(4):1274-1285

Buchan A, Gonzalez JM, Moran MA (2005) Overview of the marine Rosebacter lineage. Appl Environ Microb 71:5665-5677

Castang S, Chantegrel B, Deshayes C, Dolmazon R, Gouet P, Haser R, Reverchon S, Nasser W, Hugouvieux-Cotte-Pattat N, Doutheau A (2004) N-Sulfonyl homoserine lactones as antagonists of bacterial quorum sensing. Bioorg Med Chem Lett 14(20):5145-5149

Cataldi T, Bianco G, Frommberger M, Schmitt-Kopplin P (2004) Direct analysis of selected $\mathrm{N}$-acyl-L-homoserine lactones by gas chromatography/mass spectrometry. Rapid Commun Mass Spectrom 18(12):1341-1344

Cataldi TR, Bianco G, Palazzo L, Quaranta V (2007) Occurrence of N-acylL-homoserine lactones in extracts of some Gram-negative bacteria evaluated by gas chromatography-mass spectrometry. Anal Biochem 361(2):226-235

Davies DG, Parsek MR, Pearson JP, Iglewski BH, Costerton JW, Greenberg EP (1998) The involvement of cell-to-cell signals in the development of a bacterial biofilm. Science 280(5361):295-298

Deepa A, Marzida M, Yan GOS, Yusof MYM, Hassan H, Sekaran SD (2012) Detection of quorum sensing signal molecules and identification of an autoinducer synthase gene among biofilm forming clinical isolates of Acinetobacter spp. PLoS ONE 7(7):e36696
Fuqua C, Winans SC, Greenberg EP (1996) Census and consensus in bacterial ecosystems: the LuxR-LuxI family of quorum-sensing transcriptional regulators. Annu Rev Microbiol 50(1):727-751

Gambello MJ, Iglewski BH (1991) Cloning and characterization of the Pseudomonas aeruginosa lasR gene, a transcriptional activator of elastase expression. J Bacteriol 173(9):3000-3009

Gao J, Ma A, Zhuang X, Zhuang G (2014) An N-acyl homoserine lactone synthase in the ammonia-oxidizing bacterium Nitrosospira multiformis. Appl Environ Microbiol 80(3):951-958

Greenberg EP, Hastings J, Ulitzur S (1979) Induction of luciferase synthesis in Beneckea harveyi by other marine bacteria. Arch Microbiol 120(2):87-91

Guillard RR, Ryther JH (1962) Studies of marine planktonic diatoms: I. Cyclotella Nana Hustedt, and Detonula Confervacea (CLEVE) Gran. Can J Microbiol 8(2):229-239

Guo X, Zheng L, Zhou W, Cui Z, Han P, Tian L, Wang X (2011) A case study on chemical defense based on quorum sensing: antibacterial activity of sponge-associated bacterium Pseudoalteromonas sp. NJ6-3-1 induced by quorum sensing mechanisms. Ann Microbiol 61(2):247-255

Guo X, Liu X, Wu L, Pan J, Yang H (2016) The algicidal activity of Aeromonas sp. strain GLY-2107 against bloom-forming Microcystis aeruginosa is regulated by $\mathrm{N}$-acyl homoserine lactone-mediated quorum sensing. Environ Microbiol 18(11):3867-3883

Guzmán L, Varela R, Muller-Karger F, Lorenzoni L (2016) Bio-optical characteristics of a red tide induced by Mesodinium rubrum in the Cariaco Basin, Venezuela. J Mar Syst 160:17-25

How KY, Hong KW, Sam CK, Koh CL, Yin WF, Chan KG (2015) Unravelling the genome of long chain $\mathrm{N}$-acylhomoserine lactone-producing Acinetobacter sp. strain GG2 and identification of its quorum sensing synthase gene. Front Microbiol 6:240

Hu X, Wang Y, Yu Y, Wang D, Tian Y (2016) Research on the concentration prediction of nitrogen in red tide based on an optimal grey Verhulst model. Math Probl Eng 2:1-9

Huang Y, Li Z (2006) Chemical defense and active compounds of sponge and sponge-associated microorganisms. Biotechnol Bull 25(1):13-17

Hwang CY, Cho BC (2008) Ponticoccus litoralis gen. nov., sp nov., a marine bacterium in the family Rhodobacteraceae. Int J Syst Evol Microbiol 58:1332-1338

Ikeda T, Inoue Y, Suehiro A, Ikeshoji H, Ishida T, Takiguchi N, Kuroda A, Kato J, Ohtake $H$ (2002) The effects of cyclodextrins on autoinducer activities of quorum sensing in Pseudomonas aeruginosa. J Incl Phenom Macrocycl Chem 44(1-4):381-382

Imai I, Ishida Y, Hata Y (1992) Isolation and properties of a bacterium inhibiting the growth of Gymnodinium nagasakiense. Nippon Suisan Gakkaishi 58(6):1073-1077

Imai I, Ishida Y, Hata Y (1993) Killing of marine phytoplankton by a gliding bacterium Cytophaga sp., isolated from the coastal sea of Japan. Mar Biol 116(4):527-532

Joint I, Tait K, Wheeler G (2007) Cross-kingdom signalling: exploitation of bacterial quorum sensing molecules by the green seaweed Ulva. Philos Trans R Soc Lond B Biol Sci 362(1483):1223-1233

Karina G, Valentina P, Robert SM, Ariel K (2013) Coral-associated bacteria, quorum sensing disrupters, and the regulation of biofouling. Biofouling 29(6):669-682

Kodama M, Doucette GJ, Green DH (2006) Relationships between bacteria and harmful algae. Ecology of harmful algae. Springer, Berlin, pp 243-255

Kumar S, Stecher G, Tamura K (2016) MEGA7: molecular evolutionary genetics analysis version 7.0 for bigger datasets. Mol Biol Evol 33(7):1870-1874

Li Z, Lin S, Liu X, Tan J, Pan J, Yang H (2014) A freshwater bacterial strain, Shewanella sp. Lzh-2, isolated from Lake Taihu and its two algicidal active substances, hexahydropyrrolo [1, 2-a] pyrazine-1, 4-dione and 2, 3-indolinedione. Appl Microbiol Biotechnol 98(10):4737-4748

Li J, Nedwell DB, Beddow J, Dumbrell AJ, McKew BA, Thorpe EL, Whitby C (2015) amoA gene abundances and nitrification potential rates suggest that benthic ammonia-oxidizing bacteria and not archaea dominate $\mathrm{N}$ cycling in the Colne Estuary, United Kingdom. Appl Environ Microbiol 81(1):159-165

Mirsutani A, Takesue K, Kirita M, Ishida Y (1992) Lysis of Skeletonemacostatum by Cytophaga sp. isolated from the coastal water of the Ariake Sea. Nippon Suisan Gakkaishi 58(11):2159-2167 
Morohoshi T, Tokita K, Ito S, Saito Y, Maeda S, Kato N, Ikeda T (2013) Inhibition of quorum sensing in gram-negative bacteria by alkylamine-modified cyclodextrins. J Biosci Bioeng 116(2):175

Morohoshi T, Okutsu N, Xie X, Ikeda T (2016) Identification of Quorum-Sensing Signal Molecules and a Biosynthetic Gene in Alicycliphilus sp. isolated from activated sludge. Sensors 16(8):1218

Nakashima T, Miyazaki Y, Matsuyama Y, Muraoka W, Yamaguchi K, Oda T (2006) Producing mechanism of an algicidal compound against red tide phytoplaonkton in a marine bacterium $\gamma$-proteobacterium. Appl Microbiol Biotechnol 73(3):684-690

Nealson KH, Platt T, Hastings JW (1970) Cellular control of the synthesis and activity of the bacterial luminescent system. J Bacteriol 104(1):313-322

Parsek MR, Schaefer AL, Greenberg E (1997) Analysis of random and sitedirected mutations in rhll, a Pseudomonas aeruginosa gene encoding an acylhomoserine lactone synthase. Mol Microbiol 26(2):301-310

Roth PB, Twiner MJ, Wang Z, Dechraoui MYB, Doucette GJ (2007) Fate and distribution of brevetoxin (PbTx) following lysis of Karenia brevis by algicidal bacteria, including analysis of open A-ring derivatives. Toxicon 50(8):1175-1191

Ruby EG, McFallngai MJ (1992) A squid that glows in the night: development of an animal-bacterial mutualism. J Biotechnol 174(15):4865-4870

Singh RP, Baghel RS, Reddy CRK, Jha B (2015) Effect of quorum sensing signals produced by seaweed-associated bacteria on carpospore liberation from Gracilaria dura. Front Plant Sci 6:117

Summers W (1983) Cephalopod life cycles, Vol. I: species accounts. Academic Press, London, pp 75-91

Swift S, Karlyshev AV, Fish L, Durant EL, Winson MK, Chhabra SR, Williams P, Macintyre S, Stewart G (1997) Quorum sensing in Aeromonas hydrophila and Aeromonas salmonicida: identification of the LuxRI homologs AhyRI and AsaRI and their cognate $\mathrm{N}$-acylhomoserine lactone signal molecules. J Bacteriol 179(17):5271-5281
Tan S, Zhou J, Zhu X, Yu S, Zhan W, Wang B, Cai Z (2015) An association network analysis among microeukaryotes and bacterioplankton reveals algal bloom dynamics. J Phycol 51(1):120-132

Tang K, Zhang Y, Yu M, Shi X, Coenye T, Bossier P, Zhang XH (2013) Evaluation of a new high-throughput method for identifying quorum quenching bacteria. Scientific Rep 3:2935

Tempé J, Petit A, Holsters M, Van Montagu M, Schell J (1977) Thermosensitive step associated with transfer of the Ti plasmid during conjugation: possible relation to transformation in crown gall. Proc Natl Acad Sci 74(7):2848-2849

Wagner-Döbler I, Thiel V, Eberl L, Allgaier M, Bodor A, Meyer S, Ebner S, Hennig A, Pukall R, Schulz S (2005) Discovery of complex mixtures of novel longchain quorum sensing signals in free-living and host-associated marine alphaproteobacteria. ChemBioChem 6(12):2195-2206

Xu LY, Zheng L, Han XP, Cui ZS, Guo XC, Li XZ (2012) Screening of microalgae associated bacteria with quorum sensing system and their algicidal activity. Oceanologia ET Limnologia Sinica 43(6):1149-1155

Zan J, Heindl JE, Liu Y, Fuqua C, Hill RT (2013) The CckA-ChpT-CtrA phosphorelay system is regulated by quorum sensing and controls flagellar motility in the marine sponge symbiont Ruegeria sp. KLH11. PLoS ONE 8(6):e66346

Zheng L, Cui Z, Xu L, Sun C, Powell RJ, Hill RT (2015) Draft genome sequence of Rhodobacteraceae strain PD-2, an algicidal bacterium with a quorumsensing system, isolated from the marine microalga Prorocentrum donghaiense. Genome Announc 3(1):e01549

Zhu J, Chai Y, Zhong Z, Li S, Winans SC (2003) Agrobacterium bioassay strain for ultrasensitive detection of $\mathrm{N}$-acylhomoserine lactone-type quorumsensing molecules: detection of autoinducers in Mesorhizobium huakuii. Appl Environ Microbiol 69(11):6949-6953

\section{Submit your manuscript to a SpringerOpen ${ }^{\odot}$ journal and benefit from:}

- Convenient online submission

- Rigorous peer review

- Immediate publication on acceptance

- Open access: articles freely available online

- High visibility within the field

- Retaining the copyright to your article

Submit your next manuscript at springeropen.com 